\title{
Tracing Text Types in Biblical Hebrew
}

\author{
Wido Van Peursen \\ Vrije Universiteit Amsterdam, The Netherlands \\ w.t.van.peursen@vu.nl
}

\begin{abstract}
Weinrich's monograph Tempus: besprochene und erzählte Welt (1964) had a tremendous influence on the study of Biblical Hebrew. Studies by Schneider, Talstra and Niccacci and others are strongly influenced by Weinrich. In the етсвс database of the Hebrew Bible, initiated by Eep Talstra in the 1970s, some of Weinrich's insights have been integrated. Amidst hundreds of studies in general linguistics, why was it precisely this book that had such a great impact? How should we evaluate this impact? Are Weinrich's insights still useful or have they become outdated? In this article we describe the introduction of Weinrich's insights into Biblical studies and some developments that have taken place since then, both in general linguistics and in Biblical studies. We further describe and evaluate the classification of Biblical Hebrew text types which developed from these insights
\end{abstract}

\section{Keywords}

Biblical Hebrew - Harald Weinrich - text types - language variation - digital humanities

\section{Introduction}

It has long been recognized, both in general linguistics and in Biblical studies, that various types of communication show different use of language. ${ }^{1}$

1 This article has benefited from the input of the researchers at the Eep Talstra Centre for Bible and Computer (втсвс), especially those involved in the Syntactic Variation project (cf. below, section 6): Dirk Bakker, Janet Dyk, Marianne Kaajan, Martijn Naaijer, Femke Siebesma-Mannes, Constantijn Sikkel, Eep Talstra. 
For instance, the language of a fairy tale is different from that of a newspaper article. In the Bible, the language of a narrative text differs from that of a legal or sapiential text. These differences in language use cannot be ignored in any description of the Classical Hebrew language, especially when it comes to questions of linguistic diversity and development. Though, opinions may differ as to whether differences imply distinctions in the underlying language system, or whether they show that various genres used the underlying language system differently. ${ }^{2}$

It is true that genre is an important predictor for the distribution of linguistic constructions, but a classification of texts based on genre is not enough when it comes to the study of language variation. The genre may suggest a certain text type (e.g., fairy tale is a "narrative"), but within one text various text types may occur. When, for example, a German fairy tale ends with Und wenn sie nicht gestorben sind, so leben sie heute noch, the narrator switches from the narrative register to addressing the reader/listener directly. In the Hebrew Bible, too, we find all kinds of switches in text type: in a story, the characters may use discursive text in quoted direct speech; in direct speech sections or in texts that by default can be labelled as direct speech, such as Psalms, a short story may develop. Sometimes the narrator addresses the listener or reader directly and switches from narrative speech to discursive speech. This happens, for example, in Gen 32:33, where the narrator interrupts to address the reader/ listener directly with the explanation: "Therefore to this day the Israelites do not eat the sinew of the hip which is upon the hollow of the thigh, because he touched the hollow of Jacob's thigh on the sinew of the hip."3

Because of the importance of the various kinds of texts for linguistic analysis, the database of the Hebrew Bible developed by the Eep Talstra Centre for Bible and Computer (Етсвс) 4 includes labels for text type in all parts of the Old Testament. The label "text type" is used because of the ambiguity of the notion of "genre". Because various text types can occur in one single text, the ЕтСвС encoding considers "text type" as a feature of a clause, rather than as a feature of a larger literary unit based on literary considerations. Thus, in the example of Gen 32:33, the clauses quoted above bear the label "Discursive",

2 Cf. W. van Peursen, "New Directions in Computational Analysis of Biblical Poetry", in L. C. Jonker, G. R. Kotzé and C. M. Maier (eds.), Congress Volume Stellenbosch 2016 (Vetus Testamentum Supplements 177; Leiden: Brill, 2017), 378-894.

3 Translations follow the RSv (slight modifications not indicated), with one notable exception in Psalm 64, (below, section 5.2).

4 Published as BHSA (Biblia Hebraica Stuttgartensia Amstelodamensis), it is accessible online through the SHEBANQ website (https://shebanq.ancient-data.org); the complete database is also available at https://github.com/etcbc/bhsa. 
whereas the preceding clauses have the label "Narrative". The text type shifts that can occur within a literary unit (cf. above) would have been obscured if we had defined text type as a feature of a verse, a paragraph, or a larger literary unit.

On the basis of our preliminary observations in the previous section, text type can be defined as a feature of a clause which is indicative of the kind of communication environment the clause belongs to. The Етсвс database distinguishes three text types: ${ }^{5}$

- N Narrative

- Q Quotation

- D Discursive

This categorization takes into account the difference between narrative $(\mathrm{N})$, the kind of communication that emerges when characters begin to speak within the narrative $(Q)$, and the switch in communication that happens when the narrator addresses the reader/listener directly, as in the example from Gen 32:33 mentioned above (D). The values for text type are constructed in a cumulative manner. Thus when a direct speech $(\mathrm{Q})$ occurs within a narrative $(\mathrm{N})$, this is marked with NQ. When within a quotation another quotation occurs, this is marked NQQ. ${ }^{6}$ Hence, the value of a text type is a string of one or more characters: $\mathrm{N}, \mathrm{NQ}, \mathrm{NQQ}, \mathrm{ND}$ etc.

Sometimes this results in rather complex strings. Thus in $2 \mathrm{Kgs}$ 1:6 it is narrated $(\mathrm{N})$ that Ahaziah's messengers returned to him and told him (in direct

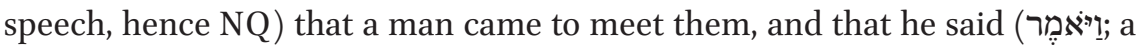
"narrative" wayyiqtol form and hence $\mathrm{N}^{7}$ within $\mathrm{Q}$, resulting in $\mathrm{NQN}$ ), that they should tell the king what the Lord says. After the man's direct speech (NQNQ): "Go back to the king (...) and say to him"; the man quotes the words that the messengers should say to their king (NQNQQ), which in turn include an oracle, introduced as God's direct speech (NQNQQQ). ${ }^{8}$

5 A fourth label is a question mark, for those cases where the text type cannot be decided upon on the basis of syntactic criteria.

6 For examples see below, section 5 .

7 For the assignment of the text type label $\mathrm{N}$ on the basis of the presence of a wayyiqtol form, see below, sections 3.3 and 4.2 .

8 A similar complexity is found in Genesis 44 with Judah's lengthy speech to Joseph, were we find NQQNQN in 44:2O and NQNQNQ in 44:28. 


\section{$3 \quad$ Theoretical Background}

\subsection{Harald Weinrich}

The insights ${ }^{9}$ underlying the labels $\mathrm{N}, \mathrm{Q}$ and $\mathrm{D}$ in the Етсвс database can be traced back to a 1964 monograph by the German linguist Harald Weinrich, entitled Tempus: besprochene und erzählte Welt. ${ }^{10}$ Weinrich developed a model that distinguishes between narrative and discursive text forms and applied it to several European languages. Weinrich's main focus was on the Romance languages, especially French. Hans-Jakob Polotsky, a great admirer of Weinrich, introduced his insights into Semitic and Egyptian studies. ${ }^{11}$ Weinrich's work further found its way in Hebrew studies due to the work of Wolfgang Schneider, Eep Talstra and Alviero Niccacci (the latter a student of Polotsky ${ }^{12}$ ). Through the work of Ariel Shisha-Halevy ${ }^{13}$ (also a student of Polotsky) it influenced Egyptian and Coptic studies and, to a lesser extent, Celtic linguistics. This work was continued by some of Shisha-Halevy's PhD students, working on Anglo-Irish and English narrative, as well as Modern Irish. ${ }^{14}$

Before discussing how these insights entered Hebrew studies through Schneider's work, we will give a brief presentation of Weinrich's main thoughts. Weinrich makes a distinction between besprechen and erzählen. This distinction corresponds roughly to that between discours and histoire that Émile Benveniste had made some years before in an essay on the French verb. ${ }^{15}$ Both Benveniste and Weinrich based their argument on the use of different verb forms, such as the passé composé and the passé simple in French, which both relate to the past and yet are clearly distinct. ${ }^{16}$ Although the relevance of

$9 \quad$ I am grateful to Dr Eitan Grossman (Hebrew University of Jerusalem) and Professor Ariel Shisha Halevy (Emertius of Hebrew University of Jerusalem) for helpful suggestions for this section.

10 H. Weinrich, Tempus: breesprochene und erzählte Welt (Stuttgart: Kohlhammer, 1964).

11 On Polotsky and Weinrich, see also R. S. Kawashima, Biblical Narrative and the Death of the Rhapsode (Bloomington: Indiana University Press 2004), p. 40.

12 Ariel Shisha Halevy, Niccacci's classmate, describes him as "an ardent follower of Polotsky in Biblical grammar and commentary" (personal communication, 23 March 2017).

13 Cf. http://en.linguistics.huji.ac.il/people/ariel-shisha-halevy.

14 Cf. O. Eshel, Narrative Grammar and Narrative Modes in Modern Irish (PhD diss., Hebrew University of Jerusalem, 2015).

15 É. Benveniste, "Les relations de temps dans le verbe français", Bulletin de la Société de Linguistique 54 (1959); reprinted in idem, Problèmes de linguistique générale (2 vols.; Paris: Gallimard, 1966-6974), I, pp. 237-75o.

16 But in the application of their insights to the French verb, Benveniste and Weinrich arrive at different classifications; cf. Weinrich, Tempus, pp. 40-01. 
Benveniste's approach to Biblical studies was recognized by scholars such as Jan Joosten ${ }^{17}$ and Robert Kawashima, ${ }^{18}$ it was Weinrich's work that became the point of reference for many subsequent Biblical Hebrew studies.

Combining the distinction between besprechen and erzählen with the notion of "perspective" leads Weinrich to the following classification of the German verb forms:

Besprechende Tempora

das zusammengesetzte Perfekt

Präsens
Erzählende Tempora

Plusquamperfekt

das einfache Perfekt

Imperfekt

Konditional

a On Null-Tempora see Weinrich, Tempus, pp. 72-23.

Weinrich appears to be aware of some of the subtleties in the application of these principles touched upon above (section 1), such as (in our terminology) the transition from $\mathrm{N}$ to $\mathrm{Q}$ or to $\mathrm{D}$. He reckons with the fact that an author can shift from one Tempusregister to another in the closing remark of a fairy tale, ${ }^{19}$ or in the transition from narrative to direct speech. ${ }^{20}$ Further, he deals with the shift from narrative to a direct address of the reader/listener that occurs in a frame story (Rahmenerzählung ${ }^{21}$ ). He also acknowledges the importance of describing these shifts on the basis of formal features, rather than of some general notion of genre. He does not deal, however, with the more complex transitions and embeddings that we marked above by such strings of letters as NQNQQ (above, section 2, end).

17 J.Joosten, "The Indicative System of the Biblical Hebrew Verb and its Literary Exploitation", in E. van Wolde (eds.), Narrative Syntax and the Hebrew Bible: Papers of the Tilburg Conference 1996 (Biblical Interpretation Series 29; Leiden, 1997), pp. 51-11, esp. 52-23. Joosten notes the similarities between the theories of Benveniste and Weinrich and highlights the importance of Benveniste's theory of linguistic levels, including the linguistic realities beyond the sentence level.

18 Kawashima, Biblical Narrative, p. 41. Kawashima prefers Benveniste's approach because of the taxonomic character of Weinrich's method.

19 Weinrich, Tempus, p. 6o; cf. above, section 1.

20 Weinrich, Tempus, p. 123.

21 Weinrich, Tempus, p. 200. 


\subsection{Wolfgang Schneider}

Weinrich's approach was introduced into Hebrew studies by Wolfgang Schneider. ${ }^{22}$ He too distinguishes between besprechen und erzählen. According to Schneider there are two sets of verbal forms that function in these two types of human communication. ${ }^{23}$ Within these two sets, the functions of the various verb forms is to indicate perspective (retrospective versus prospective) and grounding (foreground versus background). Schneider classifies the Hebrew verb forms as follows: ${ }^{24}$

\section{Mode of communication}

Narrative Discursive

\begin{tabular}{llcc}
\hline Perspective & Retro & w-(X-)qatal & w-(X-)qatal \\
& Zero & wayyiqtol & Yiqtol / imperative qatal \\
& Forward & ašeryiqtol & w-qatal \\
\hline
\end{tabular}

\subsection{Eep Talstra}

The application of Weinrich's insights to Biblical Hebrew was further elaborated upon by Talstra, who also provided a theoretical foundation for Schneider's approach. ${ }^{25}$ Thus he emphasizes that the classification of "narrative" and "discursive" should be based on syntax, and that this may lead to text type shifts within one and the same literary unit: ${ }^{26}$

It should be noticed that this distinction is a syntactical one and not one between literary genres. In a dialogue within a narrative, for instance, the discursive verbal forms are used and not the narrative forms.

Talstra gives the following descriptions of "discourse" and "narrative" on the basis of the verb forms they contain: ${ }^{27}$

22 W. Schneider, Grammatik des Biblischen Hebräisch. Ein Lehrbuch (München: Cladius Verlag, 1974).

23 Schneider, Grammatik, §48.1-1.

24 Adapted from G. J. Kalkman, Verbal Forms in Biblical Hebrew Poetry: Poetic Freedom or Linguistic System? (PhD diss., Vrije Universiteit Amsterdam, 2015), p. 88.

25 E. Talstra, "Text Grammar and Hebrew Bible. I: Elements of a Theory", BiOr 35 (1978).

26 Talstra, "Text Grammar and Hebrew Bible", p. 170.

27 Talstra, "Text Grammar and Hebrew Bible", p. 170. 
The discursive verbal forms can be found in utterances concerning the speaker and the listener, e.g. in a dialogue, a sermon, a prayer. They refer to what is present or actual in the situation of communication. Leading member of the set is the imperfect yqțl. Secondary are the perfect $q t \underline{l}$ and the consecutive perfect $w q t$ l.

The narrative verbal forms are used in utterances concerning persons or actions not present or actual in the situation, i.e. when 'I' tell 'you' about a 'him, her, it'. Central in this group is the consecutive imperfect wyqțl. Secondary is the perfect $q t$ l.

As it appears from these quotations, the verb forms used are largely decisive for the assignment of the labels "narrative" and "discourse". Talstra further distinguishes between two types of "discourse". It can occur both as direct speech within a narrative and as "direct speech" from the narrator to the reader. On this Talstra comments, after a discussion of "a dialogue within a narrative":

The same change from the narrative set to the discursive set is found when the inserted dialogue is not between two persons that figure in the story, but between the narrator and the reader. Such a 'dialogue' can be used to give an explanation (...) and in my opinion also to conclude a narrative. ${ }^{28}$

This viewpoint enables Talstra to do justice to the fact that sometimes the narrator switches from telling a story (with the verb forms that are characteristic of narrative, especially wayyiqtol) to addressing the listeners/readers with a comment (with yiqtol forms).

Talstra's work also laid the foundation for the Етсвс database, which was built under his guidance. In agreement with Talstra's observations, two labels are used for Schneider's “discursive registers": $Q$ and D, depending on the communicative context. Both labels indicate a dialogue between "I" and "you". In the case of a single $Q$ this is, for example, between a poet and God in one of the psalms. In the case of NQ this is between characters in a story, and in the case of ND between the narrator and the reader.

Some scholars continued Talstra's work in various directions of text syntax and discourse grammar. Niccacci built upon Schneider's and Talstra's work in his studies on the verbal system in Biblical Hebrew. ${ }^{29}$ Nicolai Winther-Nielsen

28 Talstra, "Text Grammar and Hebrew Bible", p. 172.

29 See especially A. Niccacci The Syntax of the Verb in Classical Hebrew Prose (transl. by W. G. E. Watson; Sheffield: Jsot Press, 1990), pp. 19-91. 
combined Talstra's text hierarchy with W. C. Mann's, C. M. I. M. Matthiessen's and S. A. Thompson's Rhetorical Structure Analysis. ${ }^{30}$ The present author combined Talstra's text-hierarchical structure with insights from Matthiesen and Thompson about subordination, embedding and discourse structure in the study of the Syriac Bible. ${ }^{31}$ The notion that linguistic phenomena can only be described adequately by accounting for their larger context (also beyond clause level) found its way into many studies on the Biblical Hebrew verbal system, participant reference and word order, with or without reference to the work of Schneider, Talstra and Niccacci.

\subsection{Further Developments}

Tracing back the origins of some of the current approaches to Biblical Hebrew leads to a remarkable observation. Biblical language studies are still appearing that build upon the framework of one author (Weinrich), or perhaps only even one book (Weinrich's Tempus), written more than half a century ago. This is even more remarkable if one realizes that Schneider, who introduced Weinrich's insights into Biblical studies, held some eccentric views, such as the complete denial of the categories of tense and aspect as relevant to the Biblical Hebrew verb. Yet, Weinrich's influence is still felt. Even in a publication as recent as Gino Kalkman's $2015 \mathrm{PhD}$ dissertation on the verbal system in Biblical Hebrew poetry, ${ }^{32}$ the Weinrich-Schneider-Talstra-Niccacci "chain" still provides the main point of reference.

This does not mean, however, that those studies that stand in this scholarly tradition have lost their connection to current linguistic insights. Weinrich's work has not become so obsolete as some people might think, and his work is still appreciated even outside the discipline of Biblical Hebrew (cf. above, section 3.1). People such as Talstra and Niccacci not only used Schneider's insights, but also improved on them in their application to Biblical studies, taking into account linguistic subtleties that are not accounted for in Weinrich's model (cf. above, sections 2, 3.1). Some scholars combined Talstra's and Niccacci's work with insights from other theories on discourse structure, such as Rhetorical Structure Analysis (above, section 3.3). Others, working with somewhat different methodological frameworks integrated some of Weinrich's insights. Thus Jan Joosten demonstrated how "the text-linguistic elaboration of the

30 Winther-Nielsen, N., A Functional Discourse Grammar of Joshua. A Computer-Assisted Rhetorical Structure Analysis (Uppsala: Almquist \& Wiksell, 1995).

31 W.Th. van Peursen, Language and Interpretation in the Syriac Text of Ben Sira. A Comparative Linguistic and Literary Study (Monographs of the Peshitta Institute Leiden 16; Leiden: Brill, 2007), chapter 26.

32 Kalkman, Verbal Forms in Biblical Hebrew Poetry. 
Weinrichian-Niccacian kind" could be made useful without abandoning the modal, temporal and aspectual functions inherent to the verb, thus avoiding Schneider's eccentric view that the categories of tense and aspect are irrelevant to the Biblical Hebrew verb. ${ }^{33}$

Concerning Weinrich's insights that found their way into the Етсвс database by the work of Eep Talstra, we also see some connections with recent trends in linguistics. The conviction that text types should be defined on syntactic, rather than on literary grounds, shows affinity with recent attempts to bridge linguistics and literary criticism. An interesting case is the volume Genre in Language, Discourse and Cognition, ${ }^{34}$ which focuses on the integration of linguistics and genre studies, addressing questions such as: how can genre-related linguistic regularities be integrated in linguistic theory? How can linguistic theoretical concepts be used for describing and explaining specific communicative functions associated with genres? How do language and genre-related phenomena interact in creating genre phenomena? In the field of Biblical studies this relates to the much debated issue about the linguistic differences between prose and poetry: can we speak of one language system that is used in different ways, or should we rather speak of the language system of prose and that of poetry as two distinct entities? (cf. above, section 1) Bridging linguistics and literary criticism has been a main concern of Biblical Hebrew text linguistic research in Weinrich's footsteps over the last decades.

Maintaining the difference between "genre" (as feature of a text of corpus) and "text type" (as a feature of a clause), as explained above (section 1), fits well into another tendency in linguistics, that aims at paying due attention to linguistic regularities in text passages and sequences of sentences. In reaction to the pragmatic turn in linguistics, we see a movement back to the observation of linguistic regularities in adjacent sentences in, for example, Carlota Smith's book Modes of Discourse. The Local Structure of Texts. ${ }^{35}$ Smith intends to counter the tendency in discourse studies to treat discourse phenomena as pragmatic rather than linguistic. She claims that the pragmatic turn is an overreaction to earlier unsuccessful linguistic approaches to discourse. If, however, one takes the text passage rather than the whole discourse, paragraph, or episode as unit of analysis, then it is possible to observe linguistic regularities

33 Joosten, "Indicative system", p. 66. See also idem, The Verbal System of Biblical Hebrew. A New Synthesis Elaborated on the Basis of Classical Prose (Jerusalem Biblical Studies 10; Jerusalem: Simor, 2012), pp. 33-35.

34 N. Stukker, W. Spooren and G. Steen (eds.) Genre in Language, Discourse and Cognition (Applications of Cognitive Linguistics 33; Berlin: De Gruyter Mouton, 2016).

35 C. S. Smith, Modes of Discourse. The Local Structure of Texts (Cambridge Studies in Linguistics 103; Cambridge: Cambridge University Press, 2003). 
in adjacent sentences. Text passages, i.e. sequences of at least two sentences, belong to different discourse modes which are determined by the types of discourse entities - events, states, generalizations, abstractions - which are introduced in the passage, and the type of progression from one discourse entity to the next. We can also see a connection here with construction grammar approaches that see syntax, semantics, and pragmatics as three interacting language modules that are the result of pairings between forms (patterns) and meaning. ${ }^{36}$

\section{4}

\section{Algorithms for Assigning Text Types}

\subsection{Data Creation Workflow}

In the preceding sections, we discussed the origins and the theoretical background of the text type labels in the Етсвс database. We will now turn to the way in which these labels are assigned. Before doing so, we will briefly introduce the data creation workflow of this database. ${ }^{37}$ This workflow is characterized by a distributional analysis of patterns, before functional assignments are made. This starts at the morphological level. At this level, all 427,000 words of the Hebrew Bible are segmented into morphemes. With language-specific auxiliary files, functions are assigned on the basis of the distribution of morphemes. After the word level analysis, the words are combined into phrases and phrases are combined into clauses. At first, this process goes linearly through the text. Thus the strings of words are divided into 268, ooo phrase atoms. These groups of words are called "atoms" because they are uninterrupted sequences in the text. Sometimes phrases can be interrupted by other elements. Therefore the next step is to link phrase atoms that are part of one phrase together, which reduces the number to 253 ,000. The same happens with clauses, which may be interrupted by other elements such as a vocative or a relative clause. ${ }^{38}$ Accordingly, the number of 91,000 clause atoms is reduced to 88,000 clauses. The same procedures are repeated with sentences (that is, the combination of, for example, a main clause and an attributive clause, or the protasis and the apodosis of a conditional clause), thus yielding 64,500

36 Cf. Adele E. Goldberg, Constructions as Work. The Nature of Generalization in Language (Oxford: Oxford University Press, 2006), p. 5 (I am indebted to Cody Kingham for this reference).

37 For more information on the етсвс data creation workflow see Cody Kingham's contribution on http://www.etcbc.nl/datacreation.

38 Cf. Ps 64:2, quoted in section 5.2, where the clause "Hear my voice" is interrupted by the vocative "God". 
sentence atoms and 63,300 sentences. ${ }^{39}$ The relations between clauses and sentences are the building blocks of the text-hierarchical analysis. ${ }^{40}$

\subsection{The Assignment of Text Types}

It is within this context of a strict form-to-function bottom-up linguistic analysis that text types are assigned. As indicated above ( sections 1, 3.3), this is done mainly on the basis of syntax. The deductions of the text types from syntactic features include the following:

- If a clause contains a wayyiqtol, the text type is $\mathrm{N}$.

- If a clause contains a yiqtol and is preceded by a clause with text type $\mathrm{N}$, the text type is ND.

- If a clause contains an imperative, a 1st or 2nd person inflection or pronoun or a vocative, the text type is $\mathrm{Q}$. If this occurs within a narrative context the text type is NQ.

- If a clause with text type $\mathrm{N}$ contains an indication of the transition from $\mathrm{N}$ to $\mathrm{Q}$, such as a quotative formula, the following clause receives the label NQ.

Such deductions are part of an automated process. Here we see that Weinrich's model was an appropriate choice for the computational approach that Eep Talstra developed. The automatic deductions of text type are only possible because of the observable features on which they are based.

Sometimes the automatic deductions lead to counter-intuitive labels that require further exploration. What does it mean, for example, if the calculations yield a text type such as QND or QNDN in Psalm 78:45 or ??NDND in Isaiah 9:20.41 These examples show that the database does not provide the final answer about all features at all linguistic level in the Hebrew Bible, but is an instrument that in itself gives rise to further research into patterns of language and communication, which in turn help improve the database. In most cases, however, the algorithms result in convincing and insightful results, including those that provide insight into complex structures such as those mentioned at the end of section 2, and those that help detect text type transitions that may escape the human reader of a text.

39 See further https://nbviewer.jupyter.org/github/annotation/tutorials/blob/master/bhsa/ start.ipynb.

40 See e.g. E. Talstra, "A Hierarchy of Clauses in Biblical Hebrew Narrative", in E. van Wolde (eds.), Narrative Syntax and the Hebrew Bible: Papers of the Tilburg Conference 1996 (Biblical Interpretation Series 29; Leiden, 1997), pp. 85-518, and in the same volume (pp. 166-68o): Talstra, "Clause Types and Textual Structure. An Experiment in Narrative Syntax".

The question mark indicates an "unknown" text type (cf. above, footnote 5). 


\section{$5 \quad$ Examples of Text Type Transitions}

\subsection{From Narrative to Quotation $(N>N Q)$ and Embedded Quotation $(N Q>N Q Q)$}

The transition from $\mathrm{N}$ to $\mathrm{NQ}$ takes place when there is a direct speech within a narrative. If the direct speech includes another direct speech, this is marked by NQQ. An example is Judges 9:54, where Abimelech calls upon his armor-bearer to kill him:

\begin{tabular}{|c|c|c|}
\hline 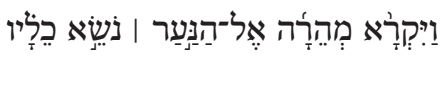 & $\mathrm{N}$ & $\begin{array}{l}\text { Then he called hastily to the young } \\
\text { man his armor-bearer, }\end{array}$ \\
\hline 1וּיָאמֶר לוֹ & $\mathrm{N}$ & and said to him, \\
\hline שׁׁלְף חַרְבְּרּ & NQ & "Draw your sword \\
\hline וּמְמוֹתְתֵנִי & NQ & and kill me, \\
\hline פַּן־יאמִמרוּ לִי & NQ & lest men say of me, \\
\hline 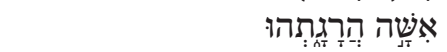 & NQQ & 'A woman killed him.”' \\
\hline 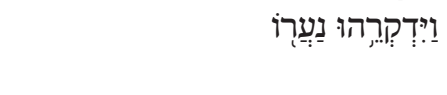 & $\mathrm{N}$ & $\begin{array}{l}\text { And his young man thrust him } \\
\text { through, }\end{array}$ \\
\hline 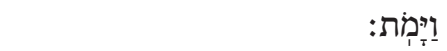 & $\mathrm{N}$ & and he died. \\
\hline
\end{tabular}

\subsection{From Quotation to Narrative $(Q>N)$}

The opposite transition occurs as well, namely from Q to N. The following example, from a psalm, illustrates very well that the definition of text type is not based on genre, but on syntax: here we have a narrative text type within a poem. The example comes from Ps 105:1-11.

\begin{tabular}{|c|c|c|}
\hline הוֹדִּו לָיהוָה & Q & ${ }^{1} \mathrm{O}$ give thanks to the Lord, \\
\hline 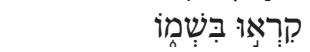 & Q & call on his name ... \\
\hline 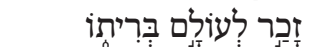 & Q & ${ }^{8} \mathrm{He}$ is mindful of his covenant for ever ... \\
\hline 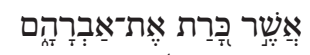 & Q & 9 that he made with Abraham ... \\
\hline 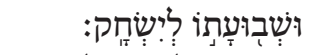 & Q & his sworn promise to Isaac, \\
\hline 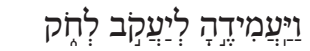 & $\mathrm{QN}$ & ${ }^{10}$ He confirmed it to Jacob as a statute, \\
\hline 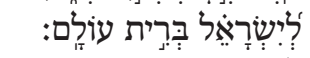 & $\mathrm{QN}$ & to Israel as an everlasting covenant, \\
\hline לִאמור & $\mathrm{QN}$ & ${ }^{11}$ saying \\
\hline 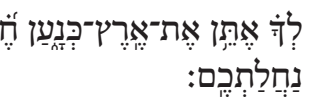 & QNQ & $\begin{array}{l}\text { "To you I will give the land of Canaan as } \\
\text { your portion for an inheritance."a }\end{array}$ \\
\hline
\end{tabular}

a An interesting question is who is the "you" in the QNQ section in verse 11, after the four names in the preceding session. Here, again we see how tekst type domains and participants interact, an area that is currently one of the main concerns of the Етсвс. 
Here we see a switch to $\mathrm{N}$, marked by a wayyiqtol in a typical Q context. The narrative that thus develops, contains itself another quotation, hence QNQ.

The following example, taken from Psalm 64, illustrates the transition from $\mathrm{Q}$ to $\mathrm{N}$ as well as that from $\mathrm{Q}$ to $\mathrm{QQ}$ :

\begin{tabular}{|c|c|c|}
\hline שְׁמַע- & Q & ${ }^{2}$ Hear, \\
\hline אֶלִהים & Q & O God, \\
\hline קָוֹלִי & Q & my voice ... \\
\hline איסַפְּרוּוּ & Q & 6 they talk \\
\hline לִטְמָמוֹן מוֹקְשׁׁים & Q & of laying snares secretly, \\
\hline 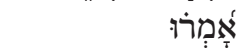 & $\mathrm{Q}$ & Thinking \\
\hline מִי יְרְאֶה־לָמוֹ: & QQ & "Who can see them?"a (...) \\
\hline 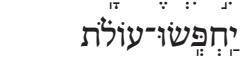 & $\mathrm{Q}$ & ${ }^{7}$ They design criminal deeds (...) \\
\hline 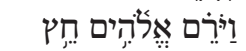 & $\mathrm{QN}$ & ${ }^{8}$ God shot at them an arrow; \\
\hline 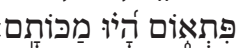 & $\mathrm{QN}$ & suddenly they were wounded \\
\hline
\end{tabular}

a Perhaps we should read with the Peshitta "us".

Many Bible translations do not recognize the "narrative" character of the wayyiqtol form and translate here with a future tense, thus e.g. Rsv: "But God will shoot his arrow at them; they will be wounded suddenly". ${ }^{42}$

The transition from Q to N, which we saw in Psalms 64 and 105, also occurs in narrative contexts. This happens when a character is speaking, but his or her direct speech switches to the narrative text type. In these cases we find a wayyiqtol in a direct speech context, and thus a small story develops. Schneider, who calls this a Sproß-Erzählung, ${ }^{43}$ describes this phenomenon as follows: ${ }^{44}$

Im besprechenden Kontext können sich an das Perfekt (rückschauende Perspektive) weiter Verbalsätze mit Narrativ anschliessen, so daß sich aus der Rückschau sekundär eine Erzählung zu entwickeln beginnt.

This happens, for example, in Jdg 9:7-71, where the direct speech of Jotham starts as follows:

42 For the wayyiqtol form in this psalm and the way in which translations and commentaries have dealt with it, see C. M. Erwich and E. Talstra, "The Text as Our Teacher: Participant Tracking in Psalm 64", in: B. J. Koet and A. L. H. M. van Wieringen (eds.), Multiple Teachers in Biblical Texts (Biblical Exegesis \& Theology 88; Leuven: Peeters, 2017), pp. $29-97$.

43 Cf. Schneider, Grammatik, §48.4.5.2.

44 Cf. Schneider, Grammatik, §48.4.5.1. 


\begin{tabular}{|c|c|c|}
\hline נוּיאמֶר לְהֶם & $\mathrm{N}$ & ${ }^{7}$ and he said to them \\
\hline 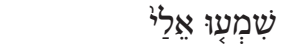 & NQ & "Listen to me, \\
\hline 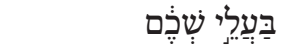 & NQ & you men of Shechem, \\
\hline 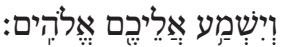 & NQ & that God may listen to you." \\
\hline 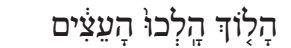 & NQ & ${ }^{8}$ The trees once went forth \\
\hline 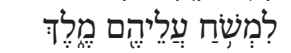 & NQ & to anoint a king over them; \\
\hline 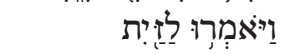 & NQN & and they said to the olive tree, \\
\hline מָלְכָה עָלָינוּ: & NQNQ & 'Reign over us.' \\
\hline
\end{tabular}

\subsection{From Narrative to Discursive $(N>N D)$}

In a discursive text the author addresses the readers directly to supply them with some background information. It is marked by the use of a yiqtol in a narrative environment. ${ }^{45}$ An example is Gen 43:32:46

\begin{tabular}{|c|c|c|}
\hline 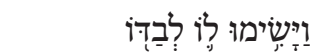 & $\mathrm{N}$ & They served him by himself \\
\hline 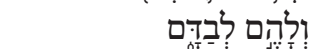 & $\mathrm{N}$ & and them by themselves \\
\hline וְלַלְּצִצְרִים & $\mathrm{N}$ & and the Egyptians \\
\hline הָאָככְלְים אִתּוֹ & $\mathrm{N}$ & who ate with him \\
\hline לְבַדָּם & $\mathrm{N}$ & by themselves \\
\hline 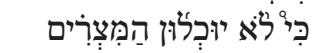 & ND & because the Egyptians could not \\
\hline 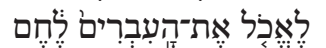 & ND & eat bread with the Hebrews \\
\hline 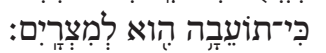 & ND & for that is an abomination to the Egyptians. \\
\hline
\end{tabular}

In section 3.3 we saw that Talstra describes this as the shift from a narrative to a dialogue between the narrator and the reader. In a similar vein, Schneider describes this phenomenon as follows: ${ }^{47}$

Der Übergang vom Narrativ zum Imperfekt innerhalb eines erzählenden Kontexts kann anzeigen, daß der Autor aus seiner Sprechhaltung als Erzähler heraustritt und mit seinen Hörern etwas bespricht, eine Anmerkung macht, die sie auch außerhalb der erzählenden Welt interessieren soll.

45 An implication of this criterion is that clauses that could be considered a comment by the narrator but do not contain a yiqtol form as not labeled as D. This applies to comment such as Gen 35:6 "And Jacob came to Luz (that is, Bethel), which is in the land of Canaan".

46 Schneider, Grammatik, §48.4.3.

47 Schneider, Grammatik, §48.4.3.1. 
The assignment of text type labels is not only valuable from a theoretical linguistic perspective, as if merely acknowledging the importance of linguistic phenomena beyond sentence level. We have seen that it is also helpful to provide insight in the complex embedding structures of narrative and direct speech. Furthermore, it turned out be useful in the study of linguistic variation in the Hebrew Bible. In a research project funded by the Netherlands Organisation for Scientific Research (Nwo), entitled "Does Syntactic Variation Reflect Language Change? Tracing Syntactic Diversity in Biblical Hebrew Texts" (2013-3017) researchers of the ЕтсвС investigated the distribution of syntactic phenomena over the Hebrew Bible. Text type was taken as one of the variables, besides text corpus and syntactic environment. This project showed the usefulness of the category of text type for accurately describing this distribution. Regarding the complexity of phrases, for example, there is a clear difference between alleged Early Biblical Hebrew texts and Late Biblical Hebrew. But this difference appears only in the narrative text type $(\mathrm{N})$, not in direct speech $(\mathrm{Q})$. At clause level, one can observe that for the various ways in which Biblical Hebrew expresses "to be", such as the nominal clause or clauses with היה, N and Q differ considerably in the alleged early texts, but Q in the early texts show some agreement with $\mathrm{N}$ and $\mathrm{Q}$ of later texts. With respect to the use of the verb היה, N (of earlier texts) shows similarities with main clauses in contrast to subordinate clauses.

These distributional patterns have been discussed in more detail elsewhere. ${ }^{48}$ For the current discussion it suffices to observe the usefulness of the category of text type in Biblical Hebrew linguistics. The integration with other categories such as the alleged date of a composition or the difference between main and subordinate clauses provide clues to advance the much debated issue of language variation and language development in the Hebrew Bible.

\section{$7 \quad$ Conclusion}

The immense influence of Weinrich's monograph Tempus. Besprochene und erzählte Welt on Biblical studies is remarkable. We traced its origin, its development and its influence on the study of other languages. Schneider, who

48 W. van Peursen, "A Computational Approach to Syntactic Diversity in the Hebrew Bible", Journal of Biblical Text Research (forthcoming). 
introduced Weinrich's work into Biblical studies, held some eccentric views, but later scholars were able to modify his approach by more recent insights both from general linguistics and from Biblical studies. A major contribution of Weinrich and Schneider and scholars who followed in their footsteps is the distinction of various text types, not based on literary considerations about a text's genre, but rather on linguistic observations. This approach, which found its way into the Етсвс database, which was initiated in the late 1970s, receives support from recent developments in general linguistics that, as a reaction to the pragmatic turn in linguistics, re-appreciate clause connections and syntactic phenomena for the description of intertextual relations beyond the clause level. The approach of Weinrich and Schneider served as a basis for the ЕтсвС not only linguistically, but also methodologically, because of its focus on observable phenomena in the text. The elaborate system of text types developed for the ЕтсвС database, which is a further development of Schneider's insights, is helpful for the analysis of complex embedding of narrative text and direct speech. An analysis of the distribution of syntactic phenomena throughout the Hebrew Bible demonstrates that text type, interacting with other factors such as genre and syntactic environment, is an important factor for describing and explaining language variation in the Hebrew Bible. 